\title{
6: 131991056-131936801
}

National Cancer Institute

\section{Source}

National Cancer Institute. 6:131991056-131936801. NCI Thesaurus. Code C41996.

Physical location of CRSP3_Gene 